\title{
Growth and yield of superior rice (Oryza sativa $L$.) varieties on different planting systems in
} \section{Papua, Indonesia}

\author{
Purwanto, O.D. ${ }^{1 *}$, F. Palobo ${ }^{2}$, and S. Tirajoh ${ }^{2}$ \\ ${ }^{1}$ Indonesian Center for Food Crops Research and Development, Jl. Merdeka No. 147, Bogor 16111, \\ West Java, Indonesia \\ ${ }^{2}$ Papua Agricultural Technology Study Center, Jl. Yahim No.49 Sentani Jayapura 99352, Indonesia
}

\begin{abstract}
Proper management of rice cultivation through the use of superior varieties and the application of a planting system adapted to site-specific conditions are very important in increasing rice yields. The purpose of this study was to determine and obtain the appropriate planting system to increase rice yield of superior varieties. The experiment adopted a split plot arranged in a randomized complete block design with two mainplot (planting systems) and three subplot (rice varieties) replicated four times. The mainplot was the planting system consisting of tile $20 \mathrm{~cm} \times 20 \mathrm{~cm}$ and legowo $4: 1(20 \mathrm{~cm}-40 \mathrm{~cm})$ $\times 10 \mathrm{~cm}$, while the subplot was rice varieties consisting of Mira 1, Inpari 32, and Inpari 34. There was an interaction effect between the planting system and the rice varieties on grain yields. Legowo 4:1 planting system showed higher grain yield than the tile planting system on the three varieties tested for this experiment. The application of the legowo 4:1 planting system on Mira 1 obtained the highest grain yield of $5.65 \mathrm{t}$ ha- 1 or increased by $5.6 \%$ compared to the tile planting system. The Mira 1 was a superior rice variety that was suitable to be applied to the planting system of legowo $4: 1(20 \mathrm{~cm}-40$ $\mathrm{cm}) \times 10 \mathrm{~cm}$ to increase rice yield.
\end{abstract}

Keywords: Grain yield, Inpari 32, Ipari 34, Legowo 4:1, Mira 1

\section{Introduction}

Rice (Oryza sativa L.) is an important food crop commodity in Indonesia and most of the people (> 90\%) consumes rice as the main staple food. The consumption of rice in 2018 reached $96.33 \mathrm{~kg}$ per capita per year with a population of around 267 million people, so rice consumption is 25.72 million tons (Sabarella et al., 2019). The need for rice is increasing in line with population growth. The growth rate of the Indonesian population in 2020-2035 is projected to be approximately $1 \%$ so that the population in 2025 will reach 285

*Corresponding author: Purwanto, O.D

Email: okydpurwanto@gmail.com

Received: August 27, 2020;

Accepted: September 28, 2020;

Published: October 6, 2020. million (BPS-Statistics Indonesia, 2013). The large population in Indonesia and the high consumption of rice are a challenge for the government in sufficing the national rice needs. The food development program has so far focused on increasing production to achieve self-sufficiency in several main foodstuffs, one of which is rice. The policy to fulfill the community's staple food, which has so far relied on rice, has an impact on the development and diet of the community which was previously based on local food and switched to rice (Rachmat, 2015).

In 2019, the rice harvest area in Indonesia reached 10.68 hectares with a production of 54.60 million tons. In Papua 
Province, rice production in 2019 was 235,340 tons with a productivity of $4.35 \mathrm{t}$ ha-1 (Prasetyo et al., 2020). The rice productivity is low and below the average national rice productivity. The low productivity is caused by improper planting methods and the lack of water availability for rice, where water availability depends on rainfall conditions. Merauke Regency is the center of rice production in Papua and has a high production potential to be developed. Rice production in Merauke Regency increases in line with the increase in the land area through the expansion of new integrated rice fields. During the 2015-2019 period, there was an addition of 8,915 ha of new paddy fields. The efforts to increase rice production can't only be done by expanding the land, but also by increasing productivity (Azkaenza et al., 2019 and BPS-Statistics of Merauke Regency, 2020).

The use of adaptive new varieties and improvements of land management methods such as the legowo planting system, soil ameliorant applications, and improved fertilization management are efforts to increase rice yields (Hafif, 2016). The planting system is one of the components of farming that affects rice yields and income. Planting systems with suitable spacing and plant population management will affect important processes in capturing solar radiation by plants for photosynthesis, absorption of nutrients by roots, adequacy of plant water needs, circulation of $\mathrm{CO} 2$ and $\mathrm{O} 2$ from photosynthesis, availability of space that determines weed populations, and microclimate under the canopy which affects the development of plant pests (Makarim et al. 2005). Wider plant spacing allows plant varieties to express their growth potential (Pratiwi et al., 2010). Wider plant spacing will increase the capture of solar radiation by the plant canopy so that plant growth will also increase such as the number of productive tillers, volume and length of roots, plant dry weight, and grain weight per hill (Hatta, 2012 and Lin et al., 2009). Instead, the dense plant spacing with a high planting population will cause a decrease in the number of tillers per hill, but the number of panicles per $\mathrm{m} 2$ will increase significantly (Mobasser et al., 2009).

Besides the planting system as one of the important components in rice cultivation, variety is also the technological component in rice cultivation, which makes a major contribution to increasing rice productivity (Sutaryo and Widodo, 2018). Superior varieties have a significant contribution of $56 \%$ in increasing national rice production (ICRR, 2007; Syahri and Somantri, 2016). Superior varieties are one of the dominant components of technological innovation and are proven to be able to increase rice production for rice farmers. The use of local seed variety is the major factor that affects the economic efficiency and total factor productivity of rice (Sadiq et al., 2018). Farmers' preferences are also important in assembling new high yielding varieties according to the characteristics that local farmers are interested in and tolerant of stress conditions at the site (Perdani et al., 2020). In general, new superior varieties have characteristics that stand out for yield potential, have agronomic advantages, and are resistant to certain pests.

Indonesian Agency for Agricultural Research and Development (IAARD) has produced various technological innovations that have been able to increase the productivity of food crops, including high yielding varieties and cropping systems, some of which have been cultivated and implemented by farmers (Mulyandari et al., 2018). The rice planting system commonly applied by farmers is the tile planting system with a distance of $25 \mathrm{~cm} \times 25$ $\mathrm{cm}, 20 \mathrm{~cm} \times 20 \mathrm{~cm}$, and the legowo row planting system, both legowo 2:1 and legowo $4: 1$. The tile planting system (square system) is 
a planting patterns with square spacing where the distance between the rows are the same as along the rows. The legowo planting system is a method of planting lowland rice with a pattern of several rows of plants interspersed with one empty row. In legowo row planting system, the planting pattern of legowo is carried out alternating between two or more (generally two or four) rows of plants and one free space row. Rice planted in free space rows is moved and inserted in rows (Abdulrachman et al., 2013; Darmawan, 2016; Pratiwi et al., 2016; and Susilastuti et al., 2018). If one empty row is interspersed with two rows of plants, it is called legowo 2:1, while if one empty row is interspersed with four rows of plants, it is called legowo $4: 1$. A rice planting system with legowo $4: 1(20 \mathrm{~cm}-40 \mathrm{~cm}) \times 10 \mathrm{~cm}$ is one of the superior technology produced by IAARD (Ikwani et al., 2013). Farm management is an important aspect to increase rice production and productivity (Panuju, 2013). Good with rice cultivation practices can be carried out by applying the right planting system and using superior varieties suitable for planting following the specific conditions of the location in the region. This study aimed at obtaining the appropriate planting system that could increase the growth and yield of superior rice varieties in Papua, Indonesia.

\section{Materials and Methods}

This research was conducted from July to October 2019 in rice fields in Kamangi Village, Tanah Miring District, Merauke Regency, Papua, Indonesia. The study site was considered lowland at an altitude of $\pm 4-20 \mathrm{~m}$ above sea level. Soil types in the study area were classified as Inceptisols subgroup Endoaquepts.

The experiment adopted a split plot arranged in a randomized complete block design with four replications on an area of \pm 3 ha. The mainplot was a planting system consisting of tile with a plant spacing $20 \mathrm{~cm} \times$ $20 \mathrm{~cm}$ and legowo 4:1 with a plant spacing (20 $\mathrm{cm}-40 \mathrm{~cm}) \times 10 \mathrm{~cm}$, while the subplot was rice varieties consisting of Mira 1, Inpari 32, and Inpari 34. The plant population in the planting system of legowo $4: 1(20 \mathrm{~cm}-40 \mathrm{~cm}) \times 10 \mathrm{~cm}$ was higher than the tile $20 \mathrm{~cm} \times 20 \mathrm{~cm}$. The plant population per hectare produced for the tile $20 \mathrm{~cm} \times 20 \mathrm{~cm}$ was $\pm 250,000$ plants, while the legowo $4: 1(20 \mathrm{~cm}-40 \mathrm{~cm}) \times 10 \mathrm{~cm}$ was \pm 400,000 plants.
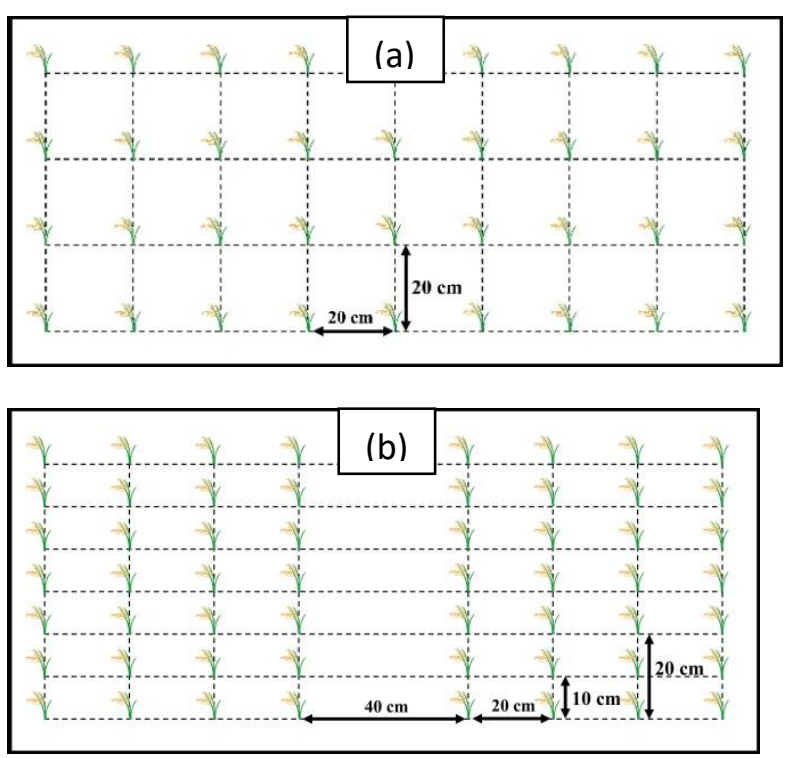

Figure 1. Treatment of the planting system (a) tile $20 \mathrm{~cm} \times 20 \mathrm{~cm}$ and (b) legowo 4:1 $(20 \mathrm{~cm}-$ $40 \mathrm{~cm}) \times 10 \mathrm{~cm}$.

Rice seeds were soaked for 24 hours until they germinated or radicle appeared. 25 days old rice seedlings were transplanted in each treatment plot with an area of $50 \mathrm{~m} \times 25$ $\mathrm{m}$ for each plot. Inorganic and organic fertilizers were applied in each plot with a dose of $150 \mathrm{~kg}$ NPK Phonska (15\% N, 15\% P2O5, $15 \% \mathrm{~K} 2 \mathrm{O}), 50 \mathrm{~kg}$ urea $(46 \% \mathrm{~N}), 100 \mathrm{~kg} \mathrm{SP}-36$ (36\% P2O5), and 3 tons of organic fertilizer per hectare. Organic fertilizer was applied 7 days before rice transplanting. SP-36 was applied at 7 days after transplanting (DAT), while NPK Phonska and urea were applied twice at 14 and 40 DAT with a dose of $50 \%$ for each 
application. During the cropping season, water availability for crops depended on rainfall and water supply for irrigation from canals that stored water during the rainy season.

Data collection was carried out on the variables of plant growth, straw weight, yield components, and grain yield. Plant growth such as plant height and number of tillers per hill were observed at the time of 30,60 , and 90 DAT. Ten hills from each plot were randomly selected to record plant height and number of tillers per hill. Plant height was measured from the base of the hills at the soil surface to the highest end of the plant (leaf tips). The number of tillers were recorded from the tillers that appeared and grew for each hill. The panicle length, number of filled grains per panicle, number of unfilled grains per panicle, and total number of grains per panicle were recorded from 10 sample units from each plot. The grain and straw yield were recorded from an area of $6.25 \mathrm{~m} 2(2.5 \mathrm{~m} \times 2.5 \mathrm{~m})$ and converted to hectares.

\section{Statistical analysis}

The data were analyzed statistically using analysis of variance (ANOVA) and then the mean value comparison test was carried out by Duncan's Multiple Range Test (DMRT) at level $\alpha=5 \%$ (Gomez and Gomez, 1984). Correlation analysis was performed to determine the relationship among agronomic characters. The data were processed using the Statistical Tool for Agricultural Research (STAR) software program version 2.01 .

\section{Results and Discussion}

\section{Climatic conditions:}

The climatic conditions at the research sites during the study were presented in Table 1 and Figure 2. The climatic conditions from July to October 2019 occurred in the dry season, which was indicated by the average rainfall per month was $22.4 \mathrm{~mm}$ and the average rainy day per month was 9 days. During the study, the average temperature was $25.5^{\circ} \mathrm{C}$ per month with an average humidity of $79 \%$ per month. The average duration of sunshine, wind velocity, and atmospheric pressure per month were 175.1 hours, 5 knots, and 1014 millibar, respectively. This low rainfall condition caused rice plants to lack water because the availability of water for plants in this experiment depended on rainfall and water supply from rainwater harvesting canals.

\section{Plant height:}

There was no interaction effect between the planting system and rice varieties on plant height. Furthermore, the planting system also did not affect plant height. The average plant height at 30,60, and 90 DAT on the treatment of the tile planting system were 58,99 , and 101 $\mathrm{cm}$ respectively, while legowo 4:1 planting system was 54, 94, and $97 \mathrm{~cm}$ (Figure3).

The rice varieties had a significant effect on rice plant height. The Mira 1 rice variety had the highest plant height at 30, 60, and 90 DAT compared to other varieties in this experiment with the average plant height produced of 72, 114, and $119 \mathrm{~cm}$, respectively. At 30 DAT, the lowest plant height was found in Inpari 32 with a plant height of $41.75 \mathrm{~cm}$ compared to other varieties. At 60 and 90 DAT, the varieties Inpari 32 and Inpari 34 had similar plant height.

\section{Rice tiller production:}

The planting system did not affect the number of tillers per hill at any growing stage, while the varieties showed a significant effect (Table 2). This showed that the influence of 
Table 1. Temperature, humidity, air pressure, duration of exposure, and wind speed from January to December 2019 in Merauke Regency.

\begin{tabular}{|c|c|c|c|c|c|c|c|c|c|}
\hline \multirow{2}{*}{ Month-Year } & \multicolumn{3}{|c|}{ Temperature $\left({ }^{\circ} \mathrm{C}\right)$} & \multicolumn{3}{|c|}{ Humidity (\%) } & \multirow{2}{*}{$\mathbf{A P}$} & \multirow{2}{*}{ DS } & \multirow{2}{*}{ WV } \\
\hline & Max & Min & Mean & Max & Min & Mean & & & \\
\hline January 2019 & 31.1 & 24.4 & 27.5 & 99 & 60 & 84 & 1009.2 & 146.2 & 5 \\
\hline February 2019 & 32.1 & 25.2 & 28.4 & 96 & 55 & 81 & 1011.0 & 176.2 & 6 \\
\hline March 2019 & 30.9 & 24.7 & 27.2 & 99 & 54 & 85 & 1010.7 & 136.1 & 4 \\
\hline April 2019 & 31.1 & 24.8 & 27.4 & 98 & 53 & 84 & 1011.2 & 176.2 & 4 \\
\hline May 2019 & 32.4 & 23.5 & 26.9 & 97 & 52 & 84 & 1012.3 & 140.5 & 4 \\
\hline June 2019 & 30.8 & 21.8 & 25.7 & 95 & 47 & 83 & 1012.6 & 118.3 & 6 \\
\hline July $2019^{1}$ & 30.4 & 19.4 & 24.7 & 94 & 45 & 81 & 1014.2 & 166.0 & 5 \\
\hline August $2019^{1}$ & 32.1 & 20.0 & 25.1 & 97 & 44 & 80 & 1014.1 & 143.1 & 5 \\
\hline September $2019^{1}$ & 30.7 & 18.6 & 25.2 & 84 & 44 & 76 & 1015.1 & 171.7 & 5 \\
\hline October $2019^{1}$ & 33.9 & 20.5 & 26.8 & 95 & 42 & 78 & 1012.4 & 219.7 & 5 \\
\hline November 2019 & 34.2 & 21.9 & 27.9 & 97 & 40 & 75 & 1010.9 & 238.3 & 5 \\
\hline December 2019 & 35.0 & 24.0 & 29.1 & 98 & 41 & 75 & 1010.1 & 250.7 & 4 \\
\hline
\end{tabular}

Data according to BPS-Statistics of Merauke Regency (2020), 1Time period of the study, AP: atmospheric pressure (MB), DS: duration of sunshine (hours), WV: wind velocity (knot).

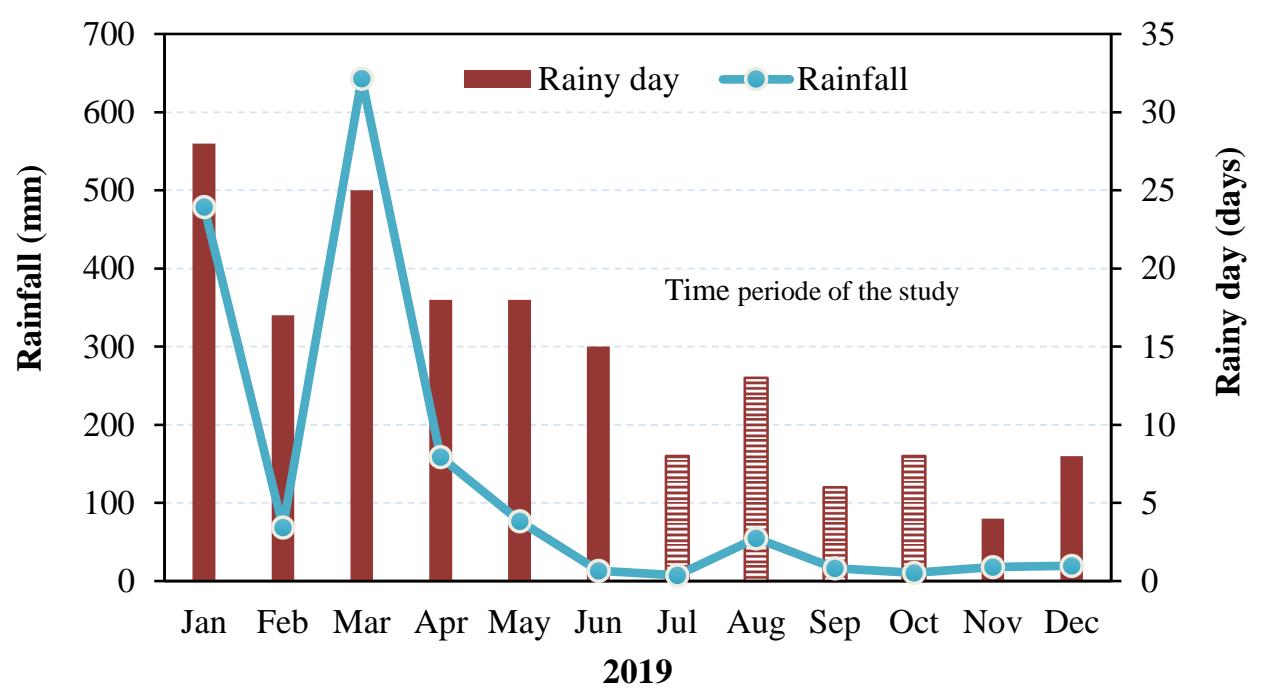

Source: BPS-Statistics of Merauke Regency (2020).

Figure 1. The climatic condition of rainfall and rainy days from January to December 2019 in Merauke Regency. 


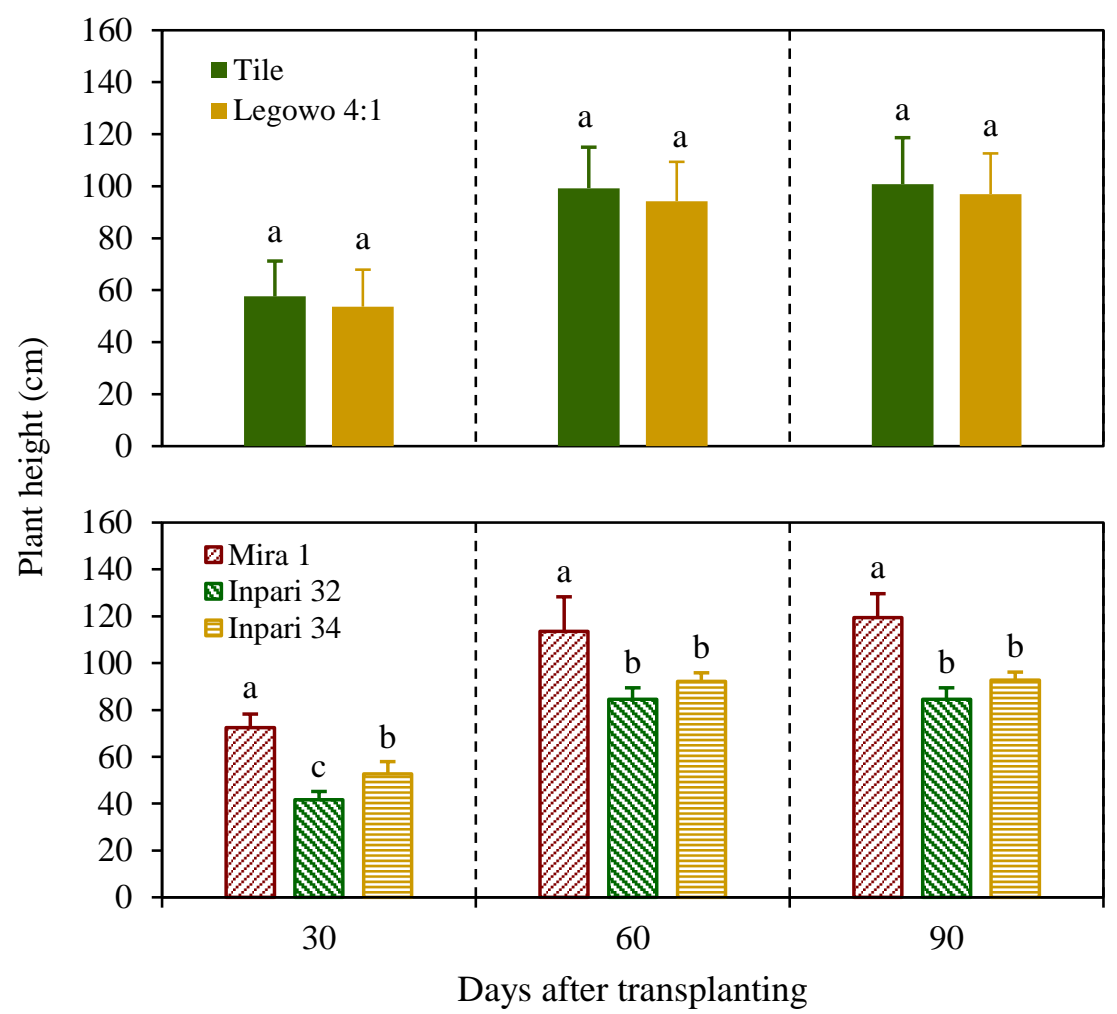

Figure 2. Effect of planting system and rice varieties on the plant height at 30, 60, and 90 days after transplanting. Mean values with the same letters above the column were not significantly different according to DMRT at the level $\alpha=5 \%$.

genetic factors on the response of tillers number in each variety was more dominant than the modification of the growing environment for plants through the application of planting systems, both tile and legowo 4:1. Environmental factors such as modification of the growing environment for plants with the tile and legowo row planting system were less mayor in influencing the growth of tiller number in this experiment and more influenced by genetic factors, i.e. the use of rice varieties. The average number of tillers per hill produced reached 16-17 tillers at 90 DAT. The response of the number of tillers per hill showed a significant difference in the rice varieties treatment. The results at 30,60, and 90 DAT showed that the Mira 1 variety had the highest number of tillers per hill compared to other varieties, while the least number of tillers per hill was found on Inpari 34. The number of tillers per hill decreased at the age of 90 DAT, compared with 60 DAT. Wang et al. (2014) reported that the number of tillers per clump tended to decline after the reproductive phase. The average number of tillers per hill at 90 DAT on varieties of Mira 1, Inpari 32, and Inpari 34 were 20, 17, and 13 tillers, respectively.

Figure 4 showed the effect of the interaction between planting systems and rice varieties on the number of tillers per hill at the age of 60 DAT. The plant density on the tile planting system $(20 \mathrm{~cm} \times 20 \mathrm{~cm})$ was lower than the legowo 4:1 $(20 \mathrm{~cm}-40 \mathrm{~cm}) \times 10 \mathrm{~cm}$, which resulted in less number of tillers per hill. Mobasser et al. (2009) stated that the number of tillers per plant was greatly influenced by cultivated variety and plant density as well as the interactions between them. The planting system of the Mira 1 variety with the tile and legowo 4:1 planting system resulted in a higher 
number of tillers per hill than other varieties, but not significantly different from the treatment of legowo $4: 1$ on the Inpari 32 variety. The variety Inpari 34 showed the least number of tillers per hill in tile planting system. Reza et al. (2012) stated that a planting system with a reduction in planting density would reduce the number of tillers and the number of effective tillers per hill.

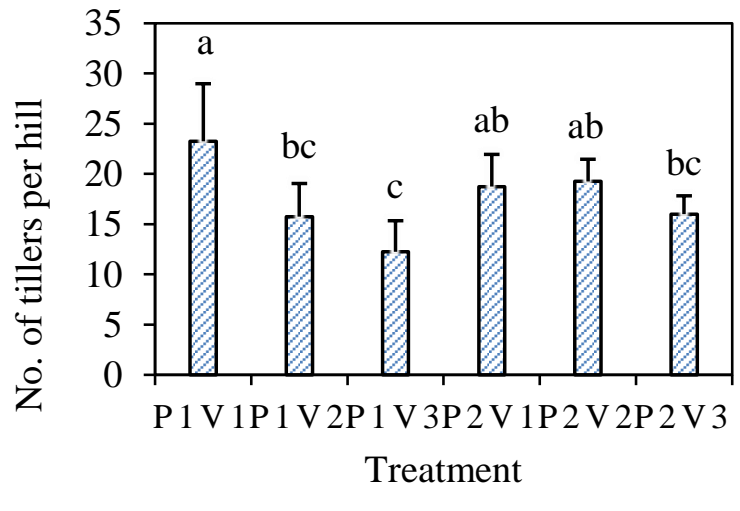

$\mathrm{P} 1=$ Tile $20 \mathrm{~cm} \times 20 \mathrm{~cm} \quad \mathrm{~V} 1=$ Mira 1

$\mathrm{P} 2=$ Legowo 4:1 $(20 \mathrm{~cm}-40 \mathrm{~cm}) \times 10 \mathrm{~cm} \mathrm{~V} 2=$ Inpari 32

Figure 4. Interactions between planting systems and rice varieties on the number of tillers per hill at 60 days after transplanting

\section{Straw yield:}

The interaction effect between planting systems and rice varieties showed a significant response to rice straw yields. Table 3 showed that the application of different planting systems affected the yield of the wet weight of rice straw on rice variety used in this experiment. This means that the use of various rice varieties to be planted must consider the suitable planting system for use and the sitespecific conditions for the plant because it would affect plant growth, which could be shown on the biomass of the vegetative character.

The Mira 1 rice variety planted with the legowo 4:1 planting system showed a higher rice straw yield compared to the tile planting system. Furthermore, the rice straw yield on the
Mira 1 variety with legowo 4:1 planting system also showed the highest yields compared to Inpari 32 and Inpari 34 varieties, both with the tile and legowo 4:1 planting system. The weight of the harvested straw produced on the Mira 1 variety with the legowo 4:1 planting system reached $16.95 \mathrm{t}$ ha- 1 or about $4 \%$ higher than the tile planting system which was only $16.28 \mathrm{t}$ ha- 1 . The effect of the planting system on the weight of rice straw produced on the Inpari 34 variety also showed a significant difference, while it was relatively not different on Inpari 32. The weight of rice straw produced by the tile planting system on Inpari 34 varieties showed higher yields than the legowo 4:1 planting system. The application of the tile planting system on Inpari 34 produced a straw yield of 15.95 t ha- 1 or about $7.8 \%$ higher than the legowo $4: 1$ which produced a straw weight of $14.80 \mathrm{t}$ ha- 1 . The response of rice straw yields on Inpari 32 did not show a significant difference. The average rice straw yield produced by applying the legowo 4:1 or tile planting system for Inpari 32 variety was 15.03 $\mathrm{t}$ ha-1. This result was not different from the Inpari 34 variety which was planted with the legowo 4:1 planting system.

This was following the results of the correlation analysis between rice plant height and straw weight, which was presented in Table 6. The relationship between plant height and straw yield has a positive and very significant correlation $\left(\mathrm{r}=0.7575^{* *}\right)$. The straw yield increased with increasing plant height. Rice that had a higher plant height tended to have greater biomass, which was characterized by an increase in the straw weight. The higher plant height and number of tillers have the potential for high yield. A good photosynthetic process would increase plant growth and dry weight (Simanjuntak et al., 2015).

\section{Yield component:}


The results of the analysis of variance showed that there was no significant effect of the planting system treatment on the rice yield components in this experiment (Table 4). There was a significant effect on the treatment of using various rice varieties, while the interaction between the planting system and the rice varieties used in this experiment did not result in any significant effect on the yield component variables.

Mira 1 variety had a longer panicle structure and the total number of grains per panicle produced was also higher than the Inpari 32 and Inpari 34 varieties. The number of unfilled grains per panicle produced in the Mira 1 variety was also lower than that of the Inpari 34 variety, but it was not significantly

Table 1. Effect of planting system and rice varieties on the number of tillers per hill at 30, 60, and 90 days after transplanting.

\begin{tabular}{|c|c|c|c|}
\hline \multirow{2}{*}{ Treatment } & \multicolumn{3}{|c|}{ Number of tillers per hill } \\
\hline & $30 \mathrm{DAT}$ & $60 \mathrm{DAT}$ & 90 DAT \\
\hline \multicolumn{4}{|c|}{ Planting system $(\mathrm{P})$} \\
\hline - Tile & 16.92 & 17.08 & 16.50 \\
\hline - Legowo 2:1 & 15.67 & 18.00 & 17.25 \\
\hline $\mathrm{F}_{\text {value }}{ }^{\mathrm{F}}$ & $1.99^{\text {ns }}$ & $0.49^{\text {ns }}$ & $0.41^{\mathrm{ns}}$ \\
\hline \multicolumn{4}{|c|}{ Rice varieties (V) } \\
\hline - Mira 1 & $23.50 \mathrm{a}^{1}$ & $21.00 \mathrm{a}$ & $20.38 \mathrm{a}$ \\
\hline - Inpari 32 & $14.13 \mathrm{~b}$ & $17.50 \mathrm{~b}$ & $16.88 \mathrm{~b}$ \\
\hline - Inpari 34 & $11.25 \mathrm{~b}$ & $14.13 \mathrm{c}$ & $13.38 \mathrm{c}$ \\
\hline $\mathrm{F}_{\text {value }}{ }^{\mathrm{F}}$ & $38.50 * *$ & $10.17 * *$ & $9.94 * *$ \\
\hline \multicolumn{4}{|c|}{ Interaction $(\mathrm{P} \times \mathrm{V})$} \\
\hline $\mathrm{F}_{\text {value }}^{\mathrm{F}}$ & $2.92^{\mathrm{ns}}$ & $4.74 *$ & $3.09^{\mathrm{ns}}$ \\
\hline
\end{tabular}

${ }^{\mathrm{F}}$ ANOVA test, ${ }^{* *}$ : significant effect at the level $\alpha=1 \%$, *: significant effect at the level $\alpha=5 \%$, ns: not significant effect, DAT: days after planting.

${ }^{1}$ Mean values followed by the different letters on the same column indicate statistical significant, according to DMRT at the level $\alpha=5 \%$.

Table 3. Interactions between planting system and rice varieties on straw yield.

\begin{tabular}{lcccc}
\hline \multirow{2}{*}{ Planting system } & \multicolumn{3}{c}{ Rice straw yield $\left(\mathrm{t} \mathrm{ha}^{-1}\right)$} & \multirow{2}{*}{ Mean $^{1}$} \\
\cline { 2 - 4 } & Mira 1 & Inpari 32 & Inpari 34 & \\
\hline Tile & $16.28 \mathrm{~b}^{1}$ & $15.23 \mathrm{c}$ & $15.95 \mathrm{~b}$ & $15.82 \mathrm{a}$ \\
Legowo 4:1 & $16.95 \mathrm{a}$ & $14.83 \mathrm{c}$ & $14.80 \mathrm{c}$ & $15.53 \mathrm{~b}$ \\
\hline Mean $^{1}$ & $16.61 \mathrm{a}$ & $15.03 \mathrm{c}$ & $15.38 \mathrm{~b}$ & \\
\hline
\end{tabular}

${ }^{1}$ Mean values followed by the different letters indicate statistically significant, according to DMRT at the level $\alpha=5 \%$. 
different from the Inpari 32 variety. The advantages of the Mira 1 variety in agronomic characters such as panicle length, the total number of grains per panicle, the number of unfilled grains per panicle, and the percentage of filled grains per panicle could be a determining factor for obtaining high rice yields. This was indicated by the relatively high percentage of filled grains on the Mira 1 variety (76.11\%) compared to the Inpari 34 variety and not significantly different from the Inpari 32 variety. The selection of cultivated variety (cultivar) was an important factor to consider in measuring the percentage of filled grains (Liu et al., 2016).

Table 4. The effect of planting system and rice varieties on the rice yield component.

\begin{tabular}{|c|c|c|c|c|}
\hline \multirow[b]{2}{*}{ Treatment } & \multicolumn{4}{|c|}{ Yield component } \\
\hline & $\begin{array}{l}\text { Panicle length } \\
\quad(\mathrm{cm})\end{array}$ & $\begin{array}{l}\text { Total number } \\
\text { of grains per } \\
\text { panicle }\end{array}$ & $\begin{array}{c}\text { Number of } \\
\text { unfilled grains } \\
\text { per panicle }\end{array}$ & $\begin{array}{c}\text { Filled grains } \\
\text { per panicle } \\
(\%)\end{array}$ \\
\hline \multicolumn{5}{|c|}{ Planting system $(\mathrm{P})$} \\
\hline - Tile & 21.61 & 135.00 & 40.08 & 70.46 \\
\hline - Legowo 4:1 & 21.74 & 124.92 & 39.00 & 69.42 \\
\hline F value $^{\mathrm{T}}$ & $0.03^{\text {ns }}$ & $0.25^{\mathrm{ns}}$ & $0.04^{\mathrm{ns}}$ & $0.05^{\mathrm{ns}}$ \\
\hline \multicolumn{5}{|c|}{ Rice varieties (V) } \\
\hline - Mira 1 & $24.34 \mathrm{a}^{1}$ & $146.13 \mathrm{a}$ & $36.13 \mathrm{~b}$ & $76.11 \mathrm{a}$ \\
\hline - Inpari 32 & $19.26 \mathrm{c}$ & $106.25 \mathrm{~b}$ & $22.38 \mathrm{~b}$ & $78.33 \mathrm{a}$ \\
\hline - Inpari 34 & $21.43 \mathrm{~b}$ & $137.50 \mathrm{a}$ & $60.13 \mathrm{a}$ & $55.37 \mathrm{~b}$ \\
\hline $\mathrm{F}_{\text {value }}{ }^{\mathrm{F}}$ & $14.58 * *$ & $6.07 *$ & $14.31 * *$ & $11.25 * *$ \\
\hline \multicolumn{5}{|c|}{ Interaction $(\mathrm{P} \times \mathrm{V})$} \\
\hline F value $^{\mp}$ & $0.07^{\mathrm{ns}}$ & $0.15^{\mathrm{ns}}$ & $2.23^{\mathrm{ns}}$ & $2.56^{\mathrm{ns}}$ \\
\hline
\end{tabular}

${ }^{\mathrm{F}}$ ANOVA test, $* *$ : significant effect at the level $\alpha=1 \%, *$ : significant effect at the level $\alpha=5 \%$, ns: not significant effect. ${ }^{1}$ Mean values followed by the different letters in the same column indicate statistical significant, according to DMRT at the level $\alpha=5 \%$.

The panicle length affected the total number of grains produced. This was presented in Table 6 which showed the relationship between panicle length and the total number of grains per panicle. The results of the correlation analysis showed that there was a positive and a moderately strong correlation between panicle length and the total number of grains per panicle $(\mathrm{r}=0.6719 * *)$. The correlation coefficient ( $r$ ) described the degree of a linear relationship between the two variables and $r$ value of 0.6 up to 0.8 indicated that the strength of the linear relationship was moderately strong
(Chan, 2003). This meant that rice varieties that had a longer panicle structure tended to produce a higher total number of grains per panicle. This result was consistent with the study of Kajonphol et al. (2018) and Mohamed (2012) which reported that the number of grains per panicle had a positive correlation with panicle length. However, a longer rice panicle would have an impact on increasing the number of unfilled grains per panicle. The number of unfilled grains per panicle would be related to the percentage of filled grains produced. The results of the correlation 
analysis showed that there was a negative and very strong correlation between the number of unfilled grains per panicle and the percentage of filled grains per panicle $(\mathrm{r}=-0.8790 * *)$. A negative value on the correlation coefficient meant that the two variables were inversely related (Chan, 2003). This indicated that the percentage of filled grains per panicle would decrease with a large number of unfilled grains per panicle produced. The high percentage of filled grains per panicle were an important component in increasing grain yield. Hairmansis et al. (2010) stated that the number of filled grains per panicle was an agronomic character that had a direct positive effect on grain yield.

\section{Grain yield:}

The interaction effect between the planting system and rice varieties showed significant differences in rice yields. The legowo 4:1 planting system resulted in higher yields than the tile planting system for each rice variety used in this experiment (Table 5). The application of legowo 4:1 planting system on the Mira 1, Inpari 32, Inpari 34 varieties could increase rice yields respectively by $5.61 \%$, $6.27 \%$, and $31.43 \%$ compared to the tile planting system. The interaction between legowo 4:1 planting system and Mira 1 varieties showed a lower rice yield increase of $5.61 \%$ compared to Inpari 32 and Inpari 34 varieties, but this treatment resulted in the highest grain yield reached $5.65 \mathrm{t}$ ha- 1 . The lowest rice yields were found in the Inpari 34 variety with the tile planting system which produced grain yields of $2.45 \mathrm{t}$ ha- 1 . This indicated that the Mira 1 variety had better yield potential than the Inpari 32 and Inpari 34 varieties, both with the application of the tile and legowo 4:1 planting system. Genetic and environmental factors were important things that must be considered in cultivating rice in a particular land which was adapted to the sitespecific conditions in the region.

Table 5. Interactions between planting system and rice varieties on rice grain yield.

\begin{tabular}{llccl}
\hline \multirow{2}{*}{ Planting system } & \multicolumn{3}{c}{ Grain yield $\left(\mathrm{t} \mathrm{ha}^{-1}\right)$} & \multirow{2}{*}{ Mean $^{1}$} \\
\cline { 2 - 4 } & Mira 1 & Inpari 32 & Inpari 34 & \\
\hline Tile & $5.35 \mathrm{bc}^{1}$ & $5.10 \mathrm{c}$ & $2.45 \mathrm{e}$ & $4.30 \mathrm{~b}$ \\
Legowo 2:1 & $5.65 \mathrm{a}$ & $5.42 \mathrm{ab}$ & $3.22 \mathrm{~d}$ & $4.77 \mathrm{a}$ \\
\hline Mean $^{1}$ & $5.50 \mathrm{a}$ & $5.26 \mathrm{~b}$ & $2.84 \mathrm{c}$ & \\
\hline
\end{tabular}

${ }^{1}$ Mean values followed by the different letters indicate statistically significant, according to DMRT at the level $\alpha=5 \%$.

Table 6 showed the relationship between the agronomic characters that had the potential to increase grain yield. The relationship among these characters could be interpreted based on the results of correlation analysis and Pearson's correlation coefficient value in this experiment. The correlation coefficient has been the statistical method most often used for the analysis of the relationship among traits
(Bewick et al., 2003 and Kozak et al., 2012). The results of the correlation analysis in this experiment showed that several characters had a positive correlation and significantly affect rice yields. Some characters had a direct effect on grain yield, i.e. the number of tillers per hill, the number of unfilled grains per panicle, and the percentage of filled grains per panicle. In this experiment, the number of tillers per hill 
had a positive and moderately strong correlation with grain yield $\left(\mathrm{r}=0.6065^{* *}\right)$. This indicated that the increase in grain yield was in line with the number of tillers produced so this character was an important factor that must be considered in rice cultivation, especially by increasing the number of productive tillers per plant. The number of productive tillers per hill had a direct positive effect on grain yield (Hairmansis et al., 2010). The efforts to increase the number of tillers were through modification of the growing environment for plants by setting the right planting system or plant spacing and selecting the appropriate varieties.

Table 2. Correlation analysis among agronomic character on three superior rice varieties.

\begin{tabular}{llllllll}
\hline Characters & PH & NT & SY & PL & TNG & NUG & PFG \\
\hline NT & $0.6182^{* *}$ & & & & & & \\
SY & $0.7575^{* *}$ & $0.2315^{\text {ns }}$ & & & & & \\
PL & $0.6759^{* *}$ & $0.3586^{\text {ns }}$ & $0.5251^{* *}$ & & & & \\
TNG & $0.4714^{*}$ & $0.2916^{\text {ns }}$ & $0.3186^{\text {ns }}$ & $0.6719^{* *}$ & & & \\
NUG & $0.1244^{\text {ns }}$ & $-0.0937^{\text {ns }}$ & $-0.0366^{\text {ns }}$ & $0.4352^{*}$ & $0.5219^{* *}$ & & \\
PFG & $0.1137^{\text {ns }}$ & $0.2483^{\text {ns }}$ & $0.2469^{\text {ns }}$ & $-0.1449^{\text {ns }}$ & $-0.1003^{\text {ns }}$ & $-0.8790^{* *}$ & \\
GY & $0.3107^{\text {ns }}$ & $0.6065^{* *}$ & $0.2387^{\text {ns }}$ & $0.1285^{\text {ns }}$ & $-0.1525^{\text {ns }}$ & $-0.5882^{* *}$ & $0.6221^{* *}$ \\
\hline
\end{tabular}

**: correlation was significant at the level $\alpha=1 \%, *$ : correlation was significant at the level $\alpha=5 \%$, ns: not significant, PH: plant height, NT: number of tillers per hill, SY: straw yield, PL: panicle length, TNG: total number of grains per panicle, NUG: number of unfilled grains per panicle, PFG: percentage of filled grains, GY: grain yield.

The number of unfilled grains per panicle directly affected the total number of grains per panicle and grain yield. The results of the correlation analysis showed that the number of unfilled grains had a fair linear relationship with the total number of grains per panicle $(r=$ $0.5219 * *)$. The higher number of unfilled grains per panicle would increase the total number of grains per panicle, but the production of a high number of unfilled grains caused a decrease in grain yield. The results of the correlation analysis showed that there was a negative correlation between the number of unfilled grains per panicle and grain yield $(\mathrm{r}=$ $-0.5882 * *)$. This meant that the increasing number of unfilled grains per panicle tended to decrease the grain yield. The rice yield would increase in line with the decrease in the number of unfilled grains per panicle so that the increase in rice yield was carried out by increasing the percentage of filled grains per panicle and reducing the number of unfilled grains per panicle. Percentage of filled grains per panicle had a positive and moderately strong correlation with grain yield $(\mathrm{r}=$ $\left.0.6221^{* *}\right)$. This indicated that high grain yield could be achieved by increasing the percentage of filled grains per panicle.

\section{Conclusions}

The selection of high yielding varieties combined with the appropriate planting system had an important influence to achieve high rice yields. There was an interaction effect between the application of the planting system and the use of varieties on rice yields. The planting system of legowo $4: 1(20 \mathrm{~cm}-40 \mathrm{~cm}) \times 10 \mathrm{~cm}$ obtained higher grain yield than the tile $20 \mathrm{~cm}$ $\times 20 \mathrm{~cm}$ for the three varieties tested (Mira 1, Inpari 32, and Inpari 34) in this study. The 
application of the legowo 4:1 $(20 \mathrm{~cm}-40 \mathrm{~cm}) \times$ $10 \mathrm{~cm}$ on the Mira 1 variety resulted in the highest grain yield of $5.65 \mathrm{t}$ ha- 1 or an increase of $5.6 \%$ compared to the tile $20 \mathrm{~cm} \times 20 \mathrm{~cm}$ planting system. The Mira 1 rice variety using the planting system of legowo $4: 1(20 \mathrm{~cm}-40$ $\mathrm{cm}) \times 10 \mathrm{~cm}$ was the best technology component for rice cultivation in this study.

\section{Acknowledgment}

We would like to thank Rodias Beda Legu, Nely Malla, and Sriyati for collecting data and the Indonesian Agency for Agricultural Research and Development (IAARD) for funding and supporting this research.

\section{References}

Abdulrachman, S., Mejaya, M.J., Agustiani, N., Gunawan, I., Sasmita, P., and Guswara, A. (2013) 'Sistem tanam legowo'. Jakarta: Indonesian Agency for Agricultural Research and Development (IAARD).

Azkaenza, M., Pratama, W.J., Togi, W., Nova, M.S., Katimko, V.A.Y., and Moldana, W. (2019) Laporan perekonomian Provinsi Papua November 2019. Available at: https://www.bi.go.id/id/publikasi/kajianekonomi-regional/papua/Pages/LaporanPerekonomian-Provinsi-Papua-November2019.aspx (Accessed: 10 August 2020).

Bewick, V., Cheek, L., and Ball, J. (2003) 'Statistics review 7: Correlation and regression', Critical Care, 7(6), pp. 451-459. doi: 10.1186/cc2401.

BPS-Statistics Indonesia. (2013) 'Indonesia population projection'. Jakarta: BPSStatistics Indonesia.

BPS-Statistics of Merauke Regency. (2020) 'Merauke Regency in figures 2020'. Papua: BPS-Statistics of Merauke Regency.

Chan, Y.H. (2003) 'Biostatistics 104. Correlational analysis', Singapore Medical Journal, 44(12), pp. 614-619.
Darmawan, M. (2016) 'Analysis of legowo row planting system and system of rice intensification (SRI) of paddy field (Oryza sativa L.) toward growth and production', Agrotech Journal, 1(1), pp. 14-18. doi: 10.31327/atj.v1i1.202.

Gomez, K., and Gomez, A. (1984) 'Statistical procedures for agricultural research (2nd ed.)'. John Wiley \& Sons, Inc.

Hafif, B. (2016) 'Optimalization of upland potential for achieving the target of one million tons increased rice production in Lampung Provinces', Jurnal Penelitian dan Pengembangan Pertanian, 35(2), pp. 81-88. doi: 10.21082/jp3.v35n2.2016.p81-88.

Hairmansis, A., Kustianto, B., Supartopo, and Suwarno. (2010) 'Correlation analysis of agronomic characters and grain yield of rice for tidal swamp areas', Indonesian Journal of Agricultural Science, 11(1), pp. 11-15. doi: 10.21082/ijas.v11n1.2010.p11-15.

Hatta, M. (2012) 'Investigating plant spacing of legowo system on growth and yield of several rice varieties in SRI method', Jurnal Agrista, 16(2), pp. 87-93.

Ikwani, Pratiwi, G.R., Paturrohman, E. and Makarim, A.K. (2013) 'Peningkatan produktivitas padi melalui penerapan jarak tanam jajar legowo', Iptek Tanaman Pangan, 8(2), pp. 72-79.

Indonesian Center for Rice Research (ICRR). (2007) 'Penelitian padi mendukung upaya peningkatan produksi beras nasional'. Jakarta: Indonesian Agency for Agricultural Research and Development (IAARD).

Kajonphol, T., Seetaput, N., Precharattana, M., and Sangsiri, C. (2018) 'Correlation and multiple regression model for economic traits of local rice (Oryza sativa L .) in upland rice system', Applied Mechanics and Materials, 879, pp. 71-77. doi: 10.4028/www.scientific.net/AMM.879.71. 
Kozak, M., Krzanowski, W., and Tartanus, M. (2012) 'Use of the correlation coefficient in agricultural sciences: problems, pitfalls and how to deal with them', Anais Da Academia Brasileira de Ciências, 84(4), pp. 1147$1156 . \quad$ doi: $10.1590 /$ S000137652012000400029.

Lin, X., Zhu, D., Chen, H., and Zhang, Y. (2009) 'Effects of plant density and nitrogen application rate on grain yield and nitrogen uptake of super hybrid rice', Rice Science, 16(2), pp. 138-142. doi: 10.1016/S16726308(08)60070-0.

Liu, T., Ji, C., Wu, W., Chen, W., Yang, B., Chen, C., Sun, C., Zhu, X., and Guo, W. (2016) 'Measurement of rice filled grain percentage based on grain shadow features', Agronomy Journal, 108(3), pp. 1070-1078. doi: 10.2134/agronj2014.0410.

Makarim, A.K., Pasaribu, D., Zaini, Z., and Las, I. 2005 'Analisis dan sintesis pengembangan model pengelolaan tanaman terpadu padi sawah'. Jakarta: Indonesian Center for Rice Research, Indonesian Agency for Agricultural Research and Development (IAARD).

Mobasser, H.R., Yadi, R., Azizi, M., Ghanbari, A.M., and Samdaliri, M. (2009) 'Effect of density on morphological characteristics related-lodging on yield and yield components in varieties rice (Oryza sativa L.) in Iran', American-Eurasian Journal of Agricultural and Environmental Science, 5(6), pp. 745-754.

Mohamed, K. (2012) 'Ranking rice (Oryza sativa L.) genotypes using multi-criteria decision making, correlation and path coefficient analysis', British Biotechnology Journal, 2(4), pp. 211-228. doi: 10.9734/BBJ/2012/1821.

Mulyandari, R.S.H., Istriningsih, Sutater, T., Nugrahani, N., Bermawie, N., Praptana, H., Pratikno, S., Hasinah, H., Humaedah, U., Muttaqien, I., Adhy, W., Wahyuni, K.,
Orbani, I., Handoko, D.D., Utami, S., Suryani, Y., Syahyuti, Marlina, L., Pamungkas, F.A., Subaidi, A., Nurjaman. (2018) '600 Teknologi Inovatif Pertanian'. Jakarta: IAARD Press.

Panuju, D.R. (2013) 'The dynamics of rice production in Indonesia 1961-2009', Journal of the Saudi Society of Agricultural Sciences, 12(1), pp. 27-37. doi: 10.1016/j.jssas.2012.05.002.

Perdani, A.Y., Mulyaningsih, E.S., Sulistyowati, Y., Suherman, Sanjaya, I., and Prastyo, M. (2020) 'Farmer's preference of 15 upland rice line in Tabalong-South Kalimantan', Jurnal Agrotek Tropika, 8(1), pp. 131-143. doi: 10.23960/jat.v8i1.3691.

Prasetyo, O.R., Amalia, R.R., Astuti, K., Khasanah, I.N., Rahmadhani, N., and Poerwaningsih, R. (2020) 'Executive summary of paddy harvested area and production in Indonesia 2019'. Jakarta,: BPSStatistics Indonesia.

Pratiwi, E., Saraswati, R., and Nursyamsi, D. (2016) 'The current status and development of biofertilizers in Indonesia: a brief overview', Proceeding 1st International Conference on Biofertilizers and Biopesticides. Taichung, Taiwan Republic of China (ROC) August 23th-23th, 2016. Taiwan: Asian Productivity Organization, pp. 31-39.

Pratiwi, G.R., Suhartatik, E., and Makarim, A.K. (2010) 'Produktivitas dan komponen hasil tanaman padi sebagai fungsi dari populasi tanaman', Inovasi teknologi padi untuk mempertahankan swasembada dan mendorong ekspor beras: proceedings of the national seminar on rice research 2009: book 2. Indonesian Center for Rice Research (ICRR), Sukamandi 2009. Sukamandi: ICRR. pp. 443-450.

Rachmat, M. (2015) 'Food development acceleration toward self-reliance, sovereign food security achievement', Forum 
Penelitian Agro Ekonomi, 33(1), pp. 1-17. doi: 10.21082/fae.v33n1.2015.1-17.

Reza, Y., Morteza, S., Hamidreza, M., Dastan, S., and Alireza, N. (2012) 'Effect of plant density on morphologic characteristics related to lodging and yield components in different rice varieties (Oriza sativa L.)', Journal of Agricultural Science, 4(1), pp. 3238. doi: 10.5539/jas.v4n1p31.

Sabarella, Komalasari, W.B., Wahyuningsih, S., Saida, M.D.N., Manurung, M., Sehusman, Rinawati and Supriyati, Y. (2019) Buletin konsumsi pangan. Available at:

http://epublikasi.setjen.pertanian.go.id/down load/file/472-buletin-konsumsi-vol-10-no-12019 (Accessed: 7 August 2020).

Sadiq, M.S., Singh, I.P., Singh, N.K., and Yakubu, G.M. (2018) 'Improving efficiency and TFP of lowland paddy rice farmers in Kwara State of Nigeria', Journal of Agricultural Sciences, 13(2), pp. 110-129. doi: 10.4038/jas.v13i2.8336.

Simanjuntak, C.P.S., Ginting, J., and Meiriani. (2015) 'Growth and production of rice in some varieties and NPK fertilizer', Jurnal Agroekoteknologi Universitas Sumatera Utara, 3(4), pp. 1416-1424.

Susilastuti, D., Aditiameri, A., and Buchori, U. (2018) 'The effect of jajar legowo planting system on Ciherang paddy varieties', Agritropica: Journal of Agricultural Sciences, $\quad 1(1), \quad$ pp. 1-8. doi:10.31186/j.agritropica.1.1.1-8.

Sutaryo, B, and Widodo, S. (2018) 'Penampilan hasil dan komponen hasil sejumlah varietas padi unggul di Kabupaten Bantul Yogyakarta', Peran teknologi agronomi dalam mempercepat penciptaan dan hilirisasi inovasi pertanian: prosiding seminar nasional Perhimpunan Agronomi Indonesia (PERAGI) 2017. IPB International Convention Center, Bogor 19 July 2017. Bogor: Penerbit IPB Press, pp. 45-50.
Syahri, and Somantri, R.U. (2016) 'The use of improved varieties resistant to pests and diseases to increase national rice production', Jurnal Penelitian Dan Pengembangan Pertanian, 35(1), pp. 25-36. doi: 10.21082/jp3.v35n1.2016.p25-36.

Wang, D., Chen, S., Wang, Z., Ji, C., Xu, C., Zhang, X., and Chauhan, B.S. (2014) 'Optimizing hill seeding density for highyielding hybrid rice in a single rice cropping system in South China', PLoS ONE, 9(10), pp. e109417. doi: 10.1371/journal.pone.0109417. 